\title{
On the Pelagic Fauna of Plymouth for September, 1897.
}

\author{
By \\ Edward T. Browne, \\ University College, London.
}

IN the Journal of this Association for 1896 (Vol. IV., No. 2, p. 168) I published a few notes on the Pelagic Fauna of Plymouth for September, 1893 and 1895. This year (1897) I again occupied a table in the Laboratory during September for the study of medusae, and also made a few entries in my notebook on the occurrence of certain animals belonging to other groups, and kept a special look-out for the animals which I noted in previous years. Unfortunately I was not able to visit Plymouth during September in 1894 and 1896, consequently the record is broken by two blank years, and spoilt for an accurate comparison of one year with another, but it shows that more Atlantic forms were present in 1895 than in 1893 or 1897.

The pelagic animals of the Plymouth district may be conveniently divided into two sets :-

1. Local forms, to which belong the larval stages of animals living on the bottom, and the medusae liberated from Hydroids.

2. Atlantic forms, which come up the Channel.

It is the latter set which produces the great yearly changes in the fauna, and which gives the greatest interest to pelagic work.

The Atlantic forms often arrive suddenly, occasionally in great shoals, like Thatia in June, 1893, and Doliolum in 1895, but usually they are rather scarce in numbers.

It is in the neighbourhood of the Eddystone, where the main Channel tide runs, that the richest tow-nettings are taken, and I have noticed that there is a difference between the fauna off the Eddystone and in the Sound. On certain days I was able to obtain tow-nettings from the Sound in the morning and from the Eddystone in the afternoon; the results were in favour of the Eddystone tow-nettings, both in quality and quantity. 
As a rule three nets were used, attached to a single rope and placed at different depths, the coarsest mesh near the bottom and the finest close to the surface.

I have drawn up two lists of medusae for September, one to show simply the presence or absence of a species for the three different years, the other to convey an idea of the abundance of medusae during September, 1897. In the latter table I have given in some cases the actual number of specimens taken, and in other cases have conveyed a general idea of the abundance of a species by using Roman numerals as symbols.

Most of the species given in the lists have been described and figured in the Proc. Zool. Soc., 1895, and another contribution to that journal is in preparation.

The table for September, 1897, shows clearly that medusae were by no means plentiful, except two species-Obelia lucifer a and Phialidium buskianum-and on certain days were very scarce. Most of the species taken are liberated from hydroids, so that their appearance and their quantity in September depend upon the breeding-time and breeding-capacity of the hydroids, which are usually conspicuous by their absence or scarcity.

During my stay at Plymouth a considerable amount of dredging was done in various localities, extending from the Sound to the Eddystone. I examined the material carefully for hydroids, especially for the minute forms, and preserved a large number of specimens for further examination. The great bulk of the hydroids taken belonged to genera which do not liberate medusae, such as Halecium, Sertularella, Plumularia, etc., and the hydroids which do liberate medusae were, with a few exceptions, Clytia, Obelia, and Perigonimus, scarce or absent. I have noticed this scarcity of the hydroids with medusae in other localities, and am not able at present to account for it. The medusae of Lar sabellarum are by no means uncommon at Plymouth and other places, yet the hydroid has only been taken once at Ilfracombe, over twenty years ago. The medusae of Hybocodon prolifer have been recorded from many parts of the British seas, including Plymouth. They sometimes occur in vast numbers, yet the hydroid has never been recorded on this side of the Atlantic, and I believe has only been taken in Massachusetts Bay. The hydroid form must be somewhere in the neighbourhood, as the medusa carries the ova upon the manubrium until the actinula stage is reached, and this stage I have taken in the tow-net.

It is quite possible that the hydroids with medusae are really scarce. A single colony is capable of liberating a vast number of medusae. A colony of Bougainvillia ramosa was dredged off the Eddystone in NEW SERIES,-VOL. v. No. 2. 
October and placed in an aquarium. In three days it liberated not less than 4450 medusae, and when the colony was preserved there was still left a good stock of young medusa buds upon the branches. (See page 189.)

\section{NOTES ON MEDUSAE. (September, 1897.)}

Obelia lucifera.-This was by far the most abundant medusa during September. On some days thousands were taken in the tow-nets.

Phialidium buskianum.-Specimens of this species were nearly always present, from the earliest to the adult stage.

Phialidium cymbaloideum.-Most of the specimens belonged to the earliest stage, with four tentacles; a few belonged to the second stage, with eight tentacles. The adult was not taken.

Lar sabellarum.-The earlier and intermediate stages were usually taken. The adult form was very scarce.

Amphinema dinema.-Nearly all belonged to early stages.

Cytceandra areolata.-Only the intermediate stages present. (For description and figures of this species see Proc. Zool. Soc., part iv., 1897.)

Lizzia blondina.-This medusa begins its free-swimming existence with four single perradial tentacles and four single interradial tentacles, and as it grows the perradial tentacles only increase in number until there are three tentacles in each of the perradial groups. The early stages have been described as distinct species, and are recorded in Haeckel's System der Medusen under the following names:-

First stage : Eight single tentacles $=$ Dysmorphosa minima .

Second stage: Four perradial groups with two tentacles and four single interradial tentacles $=$ Lizzia claparedei.

Third stage: Four perradial groups with three tentacles and four single interradial tentacles $=$ Lizzia blondina .

In the first and second stages the medusa usually buds off medusae from the wall of the stomach, and in the third stage the generative cells make their appearance. The first and second stages have also been described with ripe generative cells, and consequently regarded as adult medusae and distinct species.

During my visit to Plymouth in 1895, and also at Port Erin and Valencia Island, I have always taken the first and second stages with medusa-buds and the third stage with generative cells. This year at Plymouth I obtained specimens of the first and second stages in the same tow-netting, some with medusa-buds and others with genera- 
A TABLE showing the Distribution of Medusae during September, 1897.

\begin{tabular}{|c|c|c|c|c|c|c|c|c|c|c|c|c|c|c|c|c|c|c|c|c|c|c|c|c|c|c|c|}
\hline 1897.-ShPteMBEI & & & . & & . & 1 & 3 & 6 & 7 & 7 & 8 & 8 & 10 & 13 & 15 & 15 & 16 & 17 & 17 & 18 & 21 & 22 & 23 & 24 & 28 & 30 & 30 \\
\hline LOCALITY & - & & . & & & 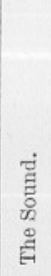 & 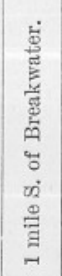 & 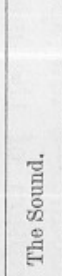 & 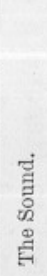 & 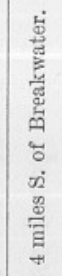 & 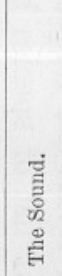 & 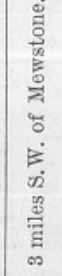 & 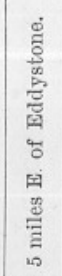 & 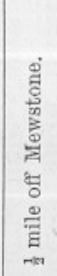 & 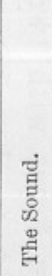 & 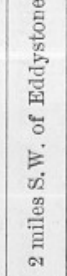 & 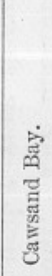 & 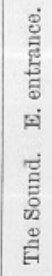 & 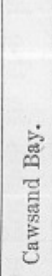 & 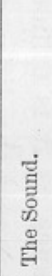 & 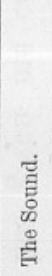 & 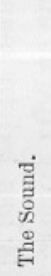 & 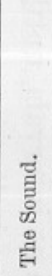 & 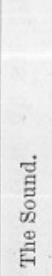 & 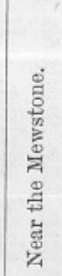 & 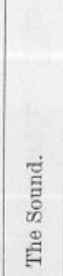 & 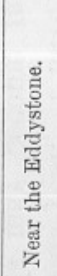 \\
\hline Obelia lucifera & . & & . & & & V. & IV. & VII. & V. & VII. & III. & VII. & IV. & IV. & II. & III. & - & I. & II. & II. & I. & II. & II. & IV. & V. & V. & IV. \\
\hline Phialidium buskianum & . & & & & . & II. & 6 & 4 & I. & 6 & I. & II. & $\mathrm{I}$. & II. & 4 & III. & II. & $\stackrel{10}{-}$ & 2 & 2 & I. & 1 & $\begin{array}{c}11 . \\
2\end{array}$ & 1 & $\vec{v}$. & IV. & III. \\
\hline Phialidium cymbaloideu & & . & . & . & . & 1 & - & 1 & - & 1 & - & 2 & - & 2 & 2 & - & - & - & 2 & - & - & 3 & 1 & 1 & 3 & 1 & - \\
\hline Lar sabellarum . . & . & & . & . & . & 2 & 2 & - & - & 1 & 一 & III. & - & 1 & - & - & - & - & 4 & - & - & - & - & 2 & 1 & - & - \\
\hline Amphinema dinema . & . & & . & . & . & 3 & - & - & - & 5 & - & 4 & 8 & 1 & - & - & 1 & - & - & - & - & - & - & - & - & 1 & - \\
\hline Cytæeandra areolata . & . & & & & . & 1 & - & - & - & 1 & 1 & 1 & $\overline{-}$ & 1 & 2 & - & - & - & 1 & - & - & - & - & - & 1 & - & - \\
\hline Lizzia blondina. . & . & & . & . & 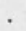 & 4 & 1 & - & - & 1 & - & 2 & III. & - & 6 & VII. & - & 1 & V. & 1 & - & - & 1 & 1 & I. & - & 1 \\
\hline Eutima insignis . & . & & & . & . & 1 & - & - & - & - & - & 一 & - & - & - & - & - & - & - & - & - & - & - & - & - & - & - \\
\hline Euphysa aurata . . & . & . & . & . & . & - & - & - & 一 & 1 & - & - & - & - & - & - & - & - & - & - & - & - & - & - & - & - & - \\
\hline Irene pellucida ${ }_{C}$. & . & & . & 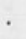 & & - & - & - & - & - & 1 & 2 & - & - & - & - & - & - & - & - & - & - & - & - & - & - & - \\
\hline Saphenia mirabilis. . & . & . & . & . & . & - & - & - & - & - & - & 1 & - & - & - & - & - & - & - & - & - & - & - & - & - & - & - \\
\hline Margelis sp? . . & . & . & . & . & & - & - & - & - & - & - & 1 & 一 & $\bar{T}$ & - & 1 & - & - & 2 & - & 1 & 一 & - & - & - & - & - \\
\hline Mitrocomium sp? . & . & . & . & . & & - & - & - & - & - & - & 1 & - & II. & - & I. & - & - & - & - & - & - & 1 & - & - & - & - \\
\hline Sarsia sp?. & . & . & & . & . & - & - & - & - & - & - & 1 & - & - & 1 & - & - & 2 & 1 & 1 & - & - & - & - & - & - & - \\
\hline Liriantha appendiculata & . & . & . & 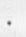 & & - & - & 一 & - & - & - & - & 3 & 1 & 1 & III. & - & 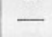 & - & - & - & - & - & 3 & III. & 1 & II. \\
\hline Sarsia gemmifera - . & . & . & & . & & - & - & 一 & - & - & - & - & 一 & - & - & - & 1 & - & - & - & - & - & - & - & - & - & - \\
\hline Gemmaria implexa . & . & . & . & . & . & - & - & - & - & - & - & - & 一 & - & - & - & - & - & 1 & - & - & - & - & - & - & - & - \\
\hline Ectopleura dumortieri & . & . & . & . & . & - & - & - & - & - & - & - & - & - & - & - & - & - & - & 1 & - & - & - & - & - & - & - \\
\hline
\end{tabular}


tive cells. The third stage was not seen this year. I have noticed in other species of medusae that the gonads may become mature in a medusa which has not reached its maximum growth. The generative cells sometimes develop and ripen faster than the medusa grows, and consequently the ova or spermatozoa are shed earlier. It is possible that a medusa may sometimes begin to shed ova at an intermediate stage of growth and continue to shed them at intervals, until it reaches its maximum growth. All the ova are not usually ripe at one time.

The early ripening of the generative cells has led to many medusae being described as distinct species. It has given me considerable trouble in tracing the life-history of a species, as it is difficult without a large number of specimens to trace and connect the different stages.

Margellium octopunctatum has often ripe gonads in the later stages, and the specimens which show the maximum growth are scarce. I have only taken them in Valencia Harbour. The maximum growth of a medusa is apparently only reached under very favourable conditions. Hybocodon prolifer when fully grown has three tentacles, but ripe generative cells are often present in forms with two tentacles. Medusae belonging to the genus Phialidium show often the early ripening of the generative cells in the intermediate stages, which has led to the description of a large number of spurious species. I believe that Saphenia mirabilis will ultimately be shown to be a stage in the development of Eutima insignis, yet both forms are frequently taken with ripe generative cells. In the present list of species both names are given, as my observations require further proof.

Cytceis $s p$. (?).-This medusa is not described in Haeckel's Monograph.

I have only found it in Plymouth Sound-a few specimens in 1893 and many in 1897. A description of the medusa, with figures, is now in preparation.

Tiara pileata.-Only young stages seen.

Euphysa aurata.-A single specimen taken. This species is new to the fauna of Plymouth.

Irene pellucida.-Only young stages seen.

Mitrocomium sp. (?).-This medusa is not described in Haeckel's Monograph. A description of the species is in preparation, as enough specimens have now been collected to connect the different stages. I obtained few specimens in 1893 and 1895.

Liriantha appendiculata. - All the specimens belonged to early stages.

Sarsia gemmifera.-A young stage with medusa-buds.

Gemmaria implexa.-An early stage. The hydroid form has not been recorded for Plymouth. 
Ectopleura dumortieri.-An early stage. This is an addition to the fauna of Plymouth. The hydroid form has not yet been recorded for Plymouth.

Agastra mira, Hartlaub.-A single specimen taken in the Sound on 31st of August. It is an addition to the Plymouth fauna. (For a description of the medusa see Proc. Zool. Soc., pt. iv., 1897.)

A List of Medusae for September only.

Obelia lucifera 1893.

1897.

$\begin{array}{llllll}. & \text { P. } & \ldots & \text { P. } & \ldots & \text { P. }\end{array}$

$\begin{array}{lllllllll}\text { Lar sabellarum } & \text {. } & \text {. } & \text {. } & \text { P. } & \ldots & \text { P. } & \ldots & \text { P. }\end{array}$

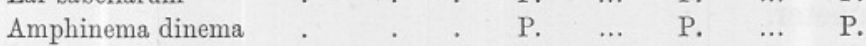

$\begin{array}{llllllll}\text { Eutima insignis } & \text {. } & \text {. } & \text { P. } & \ldots & \text { P. } & \ldots & \text { P. }\end{array}$

$\begin{array}{llllllll}\text { Saphenia mirabilis } \quad . & \text {. } & \text { P. } & \ldots & \text { P. } & \ldots & \text { P. }\end{array}$

$\begin{array}{lllllllll}\text { Irene pellucida } & . & . & . & \text { P. } & \ldots & \text { P. } & \ldots & \text { P. }\end{array}$

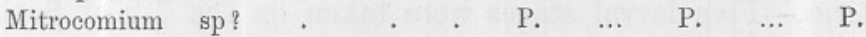

$\begin{array}{llllllll}\text { Liriantha appendiculata } & \text {. } & \text { P. } & \ldots & \text { P. } & \ldots & \text { P. }\end{array}$

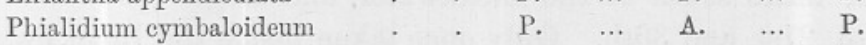

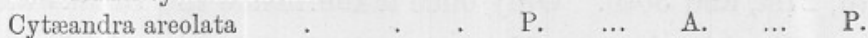

$\begin{array}{lllllllll}\text { Cytris sp? } & \text {. } & \ldots & \text {. } & \text { P. } & \ldots & \text { A. } & \ldots & \text { P. }\end{array}$

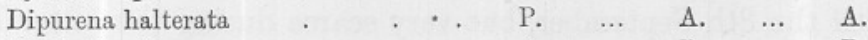

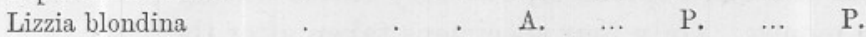

Gemmaria implexa $\quad$. $\quad$. $\quad$ A. $\quad \ldots \quad$ P. $\quad \ldots \quad$ P.

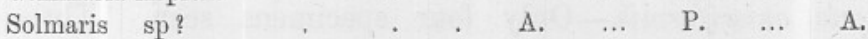

Octorchis gegenbauri $\quad$. $\quad$ A. $\quad \ldots \quad$ P. $\quad \ldots \quad$ A.

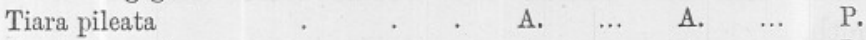

$\begin{array}{llllllll}\text { Euphysa aurata } & \text {. } & \text {. } & \text { A. } & \ldots & \text { A. } & \ldots & \text { P. }\end{array}$

Sarsia gemmifera $\quad$. $\quad$. A. $\quad$ A. $\quad$ A. $\quad \ldots \quad$ P.

Ectopleura dumortieri . $\quad$. $\quad$ A. $\quad \ldots \quad$ A. $\quad \ldots \quad$ P.

P. $=$ Present. $\quad$ A. $=$ Absent.

An Incomplete List of Animals found in the Tow-nets during

September only.

\begin{tabular}{|c|c|c|c|c|c|c|c|}
\hline Muggiæa atlantica & - & . & & $\begin{array}{c}893 . \\
\text { P. }\end{array}$ & $\ldots$ & $\begin{array}{c}1895 . \\
\text { P. }\end{array}$ & $\cdots$ \\
\hline Terebella larvae & . & . & & P. & $\ldots$ & P. & .. \\
\hline Magelona larvae & . & . & . & P. & ... & P. & $\ldots$ \\
\hline Doliolum tritonis & . & . & & P. & $\ldots$ & P. & $\ldots$ \\
\hline Noctiluca miliaris & . & . & & P. & $\ldots$ & A. & $\ldots$ \\
\hline Chætopterus larvae & . & . & & P. & $\ldots$ & A. & $\ldots$ \\
\hline Actinotrocha & . & . & & A. & ... & P. & $\ldots$ \\
\hline Tornaria & . & . & & A. & $\ldots$ & P. & $\ldots$ \\
\hline Beroe & . & . & . & A. & $\ldots$ & P. & $\ldots$ \\
\hline Pilidium & . & . & & A. & $\ldots$ & P. & $\ldots$ \\
\hline Mitraria & . & . & 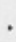 & A. & $\ldots$ & P. & $\ldots$ \\
\hline Bipinnaria & . & . & 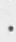 & A. & $\ldots$ & P. & $\ldots$ \\
\hline Thalia democratica & . & . & ${ }^{\circ}$ & A. & $\ldots$ & P. & $\cdots$ \\
\hline Amphioxus (larva) & . & . & . & A. & $\ldots$ & P. & $\ldots$ \\
\hline
\end{tabular}

P. $=$ Present. $\quad$ A. $=$ Absent. 
Noctiluca miliaris.-Specimens were first taken on 7th of September, about four miles outside the Breakwater. It was abundant on the 8th, three miles S.W. of the Mewstone, and on the 10th, five miles East of the Eddystone. Tow-nettings taken close to the Mewstone on the 13th did not contain any specimens. On the 15th, specimens were first taken inside the Breakwater. From the 15th to the end of the month, Noctiluca was usually present in the tow-nets. The quantity varied considerably, but it was more abundant outside than inside the Breakwater.

Cydippe.-One or two specimens were usually found in the tow-nets. They all belonged to very early stages, about 2 to $3 \mathrm{~mm}$. in diameter.

Magelona.-The larval stages of this worm were fairly common throughout the month.

Chcetopterus.-Five larval stages were taken on the 7th of September, four miles south of the Breakwater, and single specimens on the 13th, 21st, and 30th. Only once taken inside the Breakwater.

Terebella.-The larval stage, living in a little tube, was fairly common until the 8th September, but very scarce during the latter half of the month. Only four specimens taken after the 19th.

Tomopteris onisciformis.-Only four specimens seen. Three taken outside and one inside the Breakwater. About $3 \mathrm{~mm}$. in length.

Actinotrocha.-Single specimens taken on the 10th, 15th, 18th, 28th, and 30th of September. Only once taken inside the Breakwater.

Tornaria.-Single specimens taken on the 10th and 15th of September, off the Eddystone. 